\title{
Creation of Trichoderman: From an Idea to Realization
}

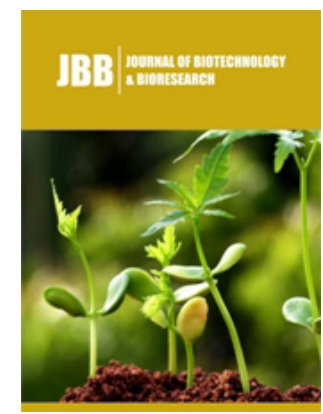

*Corresponding author: Pakdaman BS, Department of plant protection, Faculty of Agriculture, Agricultural Sciences and Natural Resources University of Khuzestan, Mollasani, Iran

Submission: 眥 April 04, 2020

Published: 監April 27, 2020

Volume 2 - Issue 3

How to cite this article: Pakdaman BS, Mohammadi N. Creation of Trichoderman: From an Idea to Realization. J Biotech Biores. 2(3). JBB.000540.2020.

Copyright@Pakdaman BS, This article is distributed under the terms of the Creative Commons Attribution 4.0 International License, which permits unrestricted use and redistribution provided that the original author and source are credited.

\author{
Pakdaman BS ${ }^{1 *}$ and Mohammadi $\mathrm{N}^{2}$ \\ ${ }^{1}$ Department of Plant Protection, Faculty of Agriculture, Iran \\ ${ }^{2}$ Dryland Agricultural Research Institute, Agricultural Research, Iran
}

\section{Abstract}

The current world of agriculture suffers from many limitations and limiting factors, and Trichoderma fungi as biologically beneficial agents can play considerable roles in soil and crop residue management, biological control of plant diseases and pests even in the niches hardly accessible by chemical pesticides, agricultural environment maintenance, as well as plant growth and yield promotion. Therefore, the creation of Trichoderma fungi via genetic transformation of superior isolates by the genetic constructs for the expression and secretion of insect-specific insecticidal peptides (Trichodermans) can improve their effectiveness in the control of insect pest targets.

Keywords: Control; Disease; Pathogen; Peptide; Pest; Trichoderma

\section{Current problems in the world of agriculture}

The present world of agriculture suffers from multiple of problems. The increasing population of the world means increased demand for agricultural production [1]. Despite of this fact, only about $5 \%$ of current agricultural soils are disease suppressive and the remnants are disease conducive [2]. While agricultural soils are exposed to increased rate of erosion and gradual loss of fertility [3], the total area for agricultural activities comes down because of increased constructions and buildings. This situation is more aggravated where the cities are expanded over agricultural regions [1]. Plants are frequently affected by mostly fungal pathogens and insect pests that invade the internal tissues which are not accessible by the pesticides. On the other hand, any increase of pesticide application dose may lead to the poisoned agricultural products which act like reservoirs and can accumulate the applied chemicals [4]. Such products may not be enough consistent to the CODEX regulations kept in developed countries and may lead to various degrees of toxicities and medical problems in consumers in ill-managed countries [5, 6]. With soil-born pests and pathogens, the application of pesticides is not so effective [7]. Pesticide molecules may be fixed to soil colloids and get deactivated, degraded by complex diversity of soil microbes, and or washed out by water movement [8]. The compensation of these losses via increased rates of application has led to increased occurrence of water and soil contamination and consequent medical and veterinary problems in human and livestock [9]. The global warmth beside of leading to increased incidence of regional and floods, threatens the already suffering agriculture via imposture of heat stress to agricultural crops, increased rate of evapotranspiration, drought and salt stress [10] in most areas of the world. The stressed plants get more sensitive to opportunistic pathogens and pests and increased crises occur in agricultural and natural vegetation [11].

\section{Biological Control and the Emergence of Trichoderman}

Trichoderma spp. are known as effective biological control agents that are isolated from soil and plants [12]. These mycoparasitic fungi are armed with different types of cell wall degrading enzymes such as chitinases [13], cellulases [14], glucanses [15], and proteases [16]. Also, they produce various volatile (such as 6-Pebtenyl Alpha Pyrone, 6-PAP) and involatile antibiotics [17], as well as a range of peptaibiotics [18] and lipases [19] that make them competent disruptors of microbial cell membranes [20] and capable of insectcutin destruction [21]. This rich arsenal leads to their unique abilities to control a range of 
plant pathogenic fungi, oomycetes, gram-positive as well as gramnegative bacteria [22], nematodes [23], and even insect pest [24]. The fungi produce huge amounts of green spores expected to be more UV-resistant than the hyaline spores of the entomopathogenic fungi such as Beauveria Bassiana [25]. Trichoderma spp. are easily cultivated on simple media are among potent competitors able to fast colonize various substrates [26] and niches on plants [27]. Importantly, these fungi are able to induce plant defensive system through salicylic acid, jasmonic acid and ethylene signaling pathways [28-32]. Unlike chemical inducers of plant resistance that lead to reduced crop yield as the result of matter and energy costs put for the motivation of plant defensive machinery, Trichoderma spp. also promote plant growth and yield [33-36] and increase their tolerance to heat, salinity and drought stresses [37]. Trichoderma spp. are well-known mycoremediants. Interestingly, Trichoderma spp. and other beneficial fungi such as arbuscular mycorrhizal fungi and Serendipita indica synergistically impose positive effects on plant growth and yield [26]. These fast growing filamentous fungi produce numerous number of actively secretive hyphal tips and since have extensively been applied for heterologous protein production and secretion [38]. The hyphal structure can penetrate into various solid substrates including plant residues, and the body of invaded (micro) organisms [39].

Therefore, Trichoderma spp. seem to fulfill most of the requirements in an ecofriendly agricultural system. However, some enzymatic differences have been found in alcohol dehydrogenase, acetyl CoA synthetase, pyruvate decarboxylase, and aldehyde dehydrogenase between Trichoderma reesei and the entomopathogenic fungus, Metarhizium anisopliae [40]. As the metabolic engineering seems rather difficult and time-consuming, the superior isolates of Trichoderma spp. can be genetically engineered in order to produce and secrete a range of insecticidal peptides. I have called these genetically transformed superiors as Trichodermans [25]. These are able to use their signal transduction pathway [41] in order to pursue the parasitic fungi as well as insects, grow toward more humid areas and infect the concealed evils in planta. Different insect-specific insecticidal neurotoxic peptides have been identified in arachnida (such as spiders and scorpions), cnidarians and mollusks that target specific sites on metal ion channels [42, 43]. Although, it is believed that spider insecticidal peptides globose (easy to be secreted) and more stable (resistant to proteases) [44], the co-transformation of superior T. asperelloides isolates with a genetic construct for the expression and secretion of $\mu$-agatoxin IV (a neurotoxin from American funnel web spider, Agelenopsis aperta) using Trichoderma harzianum $42 \mathrm{KDa}$ endochitinase signaling peptide was not successful. The reason seemed to be the endoplasmic reticulum stress imposed due to the short length of the peptide (37 aa) and four intramolecular disulfide bonds [45]. Another reasom might be that the natural toxin is of an amidated carboxylic end and such an amidation might have not been taken place in T. asperelloides. The construct was successfully expressed (as revealed by the bicistronic expression of eGFP), however, fungal conidiation was inhibited possibly due to the ER- and the subsequent secretory-stress inhibited [25].
There are other insecticidal peptides that target different sites on sodium, calcium, and potassium ion channels of insect neurotic system. For example, hainantoxins and huwentoxins specifically target site-1 on votalge-gate sodium channels [46]. Alpha-insect toxins are another group of insect-specific toxins of insect origin that target site- 3 on sodium pumps [47]. Interestingly, at least some of the insecticidal peptides are insect group-selective and even species-selective [48]. Making it possible to control deleterious insect pests without harmful impacts on beneficial insects. Anyway, biking toward the realization of Trichoderman can be peddled using other insecticidal peptides.(Figure 1)

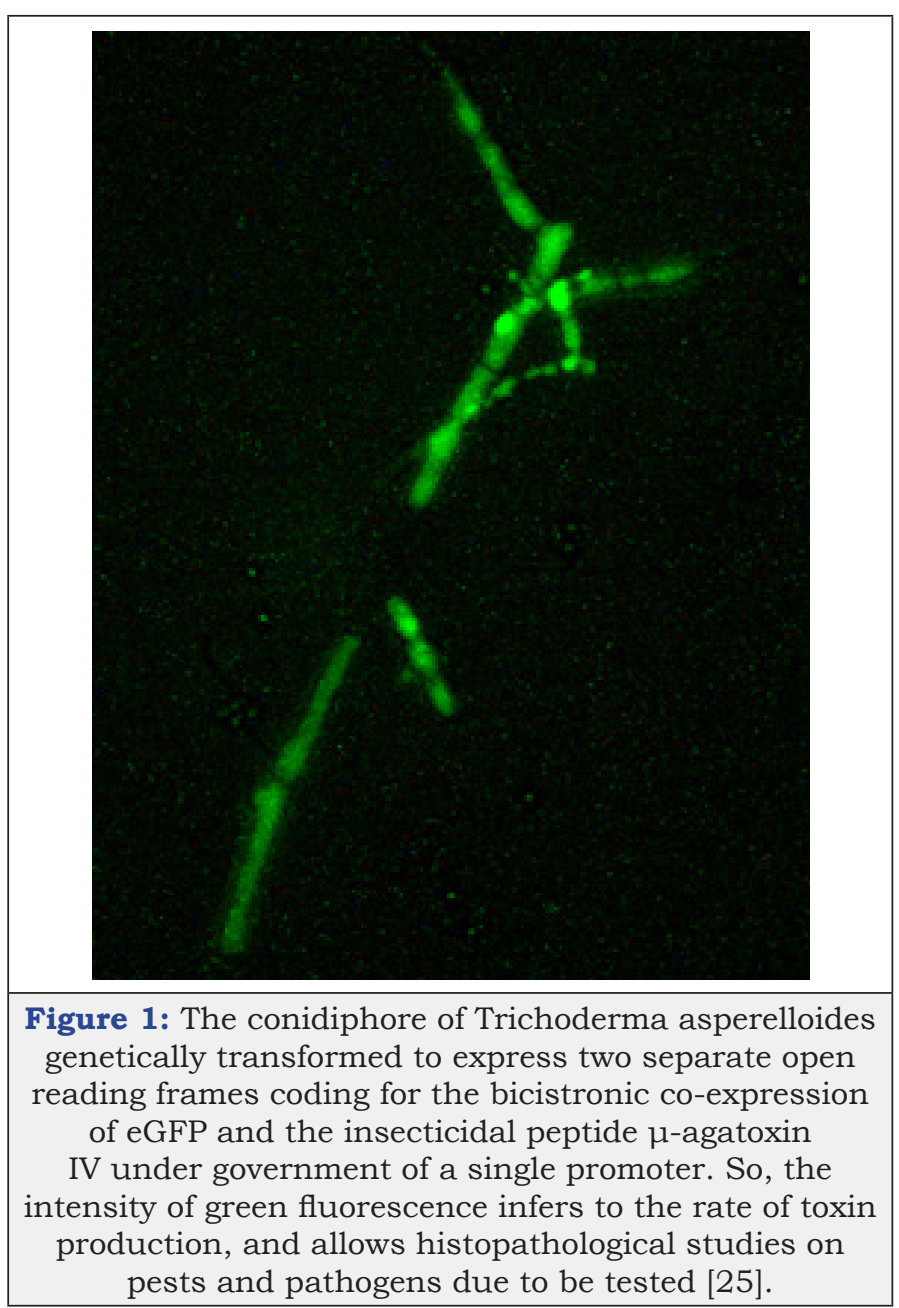

\section{References}

1. Keating BA, Herrero M, Carberry PS, Gardner J, Cole MB (2014) Food wedges: Framing the global food demand and supply challenge towards 2050. Global Food Security 3(3-4): 125-132.

2. Schlatter D, Kinkel L, Thomashow L, Weller D, Paulitz T (2017) Disease suppressive soils: New insights from the soil microbiome. Phytopathology 107(11): 1284-1297.

3. Ding Y, Liu Y, Liu S, Li Z, Tan X, et al. (2016) Biochar to improve soil fertility. A review. Agronomy for Sustainable Development 36: 1-18.

4. Uqab B, Mudasir S, Nazir R (2016) Review on bioremediation of pesticides. Journal of Bioremediation Biodegradation 7(3): 1-5.

5. Sarwar M (2015) The dangers of pesticides associated with public health and preventing of the risks. International Journal of Bioinformatics and Biomedical Engineering 1(2): 130-136. 
6. Klátyik S, Bohus P, Darvas B, Székács A (2017) Authorization and toxicity of veterinary drugs and plant protection products: residues of the active ingredients in food and feed and toxicity problems related to adjuvants. Front vet Sci 4: 1-21.

7. Lamichhane JR, Dürr C, Schwanck AA, Robin MH, Sarthou JP, et al. (2017) Integrated management of damping-off diseases. A review. Agronomy for Sustainable Development 37: 1-25.

8. Vryzas Z (2018) Pesticide fate in soil-sediment-water environment in relation to contamination preventing actions. Current Opinion in Environmental Science \& Health 4: 5-9.

9. Thompson LA, Darwish WS (2019) Environmental chemical contaminants in food: Review of a global problem. J Toxicol 2019: 1-14.

10. Colmer TD, Barton L (2017) A review of warm-season turfgrass evapotranspiration, responses to deficit irrigation, and drought resistance. Crop Science 57(S1): S98-S110.

11. Servin A, Elmer W, Mukherjee A, Torre-Roche RDe la, Hamdi H, et al. (2015) A review of the use of engineered nanomaterials to suppress plant disease and enhance crop yield. Journal of Nanoparticle Research 17.

12. O’Brien PA (2017) Biological control of plant diseases. Australasian Plant Pathology 46: 293-304.

13. Ihrmark K, Asmail N, Ubhayasekera W, Melin P, Stenlid J, et al. (2010) Comparative molecular evolution of Trichoderma chitinases in response to mycoparasitic interactions. Evol Bioinform Online 15(6): 1-26.

14. Do LH, Filho XF, Miller RN, Ricart CA, De Sousa MV (2014) Cellulase systems in Trichoderma: an overview, in Biotechnology and Biology of Trichoderma. Elsevier, Netherlands, pp. 229-244.

15. Djonović S, Vargas WA, Kolomiets MV, Horndeski M, Wiest A, et al. (2007) A proteinaceous elicitor $\mathrm{Sm} 1$ from the beneficial fungus Trichoderma virens is required for induced systemic resistance in maize. Plant Physiol 145(3): 875-889

16. Kredics L, Antal Z, Szekeres A, Hatvani L, Manczinger L, et al. (2005) Extracellular proteases of Trichoderma species. Acta Microbiologica et Immunologica Hungarica 52(2): 169-184.

17. Mohiddin F, Khan MR, Khan SM, Bhat BH (2011) Why Trichoderma is considered super hero (super fungus) against the evil parasites? Plant Pathology Journal 9(3): 92-102.

18. Marik T, Tyagi C, Balázs D, Urbán P, Szepesi Á, et al. (2019) Structural diversity and bioactivities of peptaibol compounds from the longibrachiatum clade of the filamentous fungal genus Trichoderma. Front Microbiol 10: 1-38.

19. Canseco-Pérez MA, Castillo-Avila GM, Chi-Manzanero B, Islas-Flores I, Apolinar MM, et al. (2018) Fungal screening on olive oil for extracellular triacylglycerol lipases: Selection of a Trichoderma harzianum strain and genome wide search for the genes. Genes (Basel) 9(2): 62.

20. Guha S, Ghimire J, Wu E, Wimley WC (2019) Mechanistic landscape of membrane-permeabilizing peptides. Chem Rev 119(9): 6040-6085.

21. Chávez KF, Navarro SR, Mayagoitia JC, Florido JB (2011) Enzymes and toxins of entomopathogenic fungi, their potential application as insecticides and fungicides. Rural Societies, Production and the Environment 11(22): 143-160.

22. Leelavathi MS, Vani L, Reena P (2014) Antimicrobial activity of Trichoderma harzianum against bacteria and fungi. International Journal of Current Microbiology and Applied Sciences. 3(1): 96-103.

23. Szabó M, Csepregi K, Gálber M, Virányi F, Fekete C (2012) Control plant-parasitic nematodes with Trichoderma species and nematodetrapping fungi: the role of chi18-5 and chi18-12 genes in nematode eggparasitism. Biological Control 63(2): 121-128.
24. Shakeri J, Foster HA (2007) Proteolytic activity and antibiotic production by Trichoderma harzianum in relation to pathogenicity to insects. Enzyme and Microbial Technology 40(4): 961-968.

25. Pakdaman BS (2013) Study on the Enthomopathogenicity of Trichoderma species and the generation of a transgenic Trichoderma for the effective biocontrol of insect and fungal pests. Tarbiat Modares University, p. 397.

26. Poveda J, Hermosa R, Monte E, Nicolás C (2019) Trichoderma harzianum favours the access of arbuscular mycorrhizal fungi to non-host Brassicaceae roots and increases plant productivity. Scientific Reports 9: 1-11.

27. Sarrocco S, Guidi L, Fambrini S, Degl'Innocenti E, Vannacci G (2009) Competition for cellulose exploitation between Rhizoctonia Solani and two Trichoderma isolates in the decomposition of wheat straw. Journal of Plant Pathology 91(2): 331-338.

28. Bisen K, C Keswani, J Patel, B SarmaH Singh, (2016) Trichoderma spp.: Efficient inducers of systemic resistance in plants, in Microbial-mediated induced systemic resistance in plants. Springer, Germany, pp. 185-195.

29. Contreras-Cornejo HA, López-Bucio JS, Bravo AM, Rodríguez LM, Vega MR, et al. (2015) Mitogen-activated protein kinase 6 and ethylene and auxin signaling pathways are involved in Arabidopsis root-system architecture alterations by Trichoderma atroviride. Mol Plant-Microbe Interact 28(6): 701-710.

30. Leonetti P, Zonno MC, Molinari S, Altomare C (2017) Induction of SAsignaling pathway and ethylene biosynthesis in Trichoderma harzianumtreated tomato plants after infection of the root-knot nematode Meloidogyne incognita. Plant Cell Rep 36(4): 621-631.

31. Nguyen EV, Imanishi SY, Haapaniemi P, Yadav A, Saloheimo M, et al. (2016) Quantitative site-specific phosphoproteomics of Trichoderma Reesei signaling pathways upon induction of hydrolytic enzyme production. Journal of Proteome Res 15(2): 457-467.

32. Nieto-Jacobo MF, Steyaert JM, Salazar-Badillo FB, Nguyen DV, Rostás M, et al. (2017) Environmental growth conditions of Trichoderma spp. affects indole acetic acid derivatives, volatile organic compounds, and plant growth promotion. Front Plant Sci 8: 1-18.

33. França DVC, Kupper KC, Magri MR, Gomes TM, Rossi F (2017) Trichoderma spp. Isolates with potential of phosphate solubilization and growth promotion in cherry tomato ${ }^{1}$. Tropical Agriculture Research 47(4): 360-368.

34. Lee S, Yap M, Behringer G, Hung R, Bennett JW (2016) Volatile organic compounds emitted by Trichoderma species mediate plant growth. Fungal Biology and Biotechnology 3: 1-14.

35. Singh V, Upadhyay RS, Sarma BK, Singh HB (2016) Seed bio-priming with Trichoderma asperellum effectively modulate plant growth promotion in pea. International Journal of Agriculture, Environment and Biotechnology 9(3): 361-365.

36. Stewart AR Hill (2014) Biotechnology and Biology of Trichoderma.

37. Poveda J (2020) Trichoderma parareesei favors the tolerance of rapeseed (Brassica Napus L.) to Salinity and Drought Due to a chorismate mutase. Agronomy 10(1): 118.

38. Rantasalo A, Vitikainen M, Paasikallio T, Jäntti J, Landowski CP, et al. (2019) Novel genetic tools that enable highly pure protein production in Trichoderma reesei. Scientific Reports 9: 1-12.

39. Druzhinina IS, Seiboth VS, Estrella AH, BA Horwitz, Kenerley CM, et al. (2011) Trichoderma: The genomics of opportunistic success. Nat Rev Microbiol 9(10): 749-759.

40. Freimoser FM, Hu G, St Leger RJ (2005) Variation in gene expression patterns as the insect pathogen Metarhizium anisopliae adapts to different host cuticles or nutrient deprivation in vitro. Microbiology 151(Pt 2): 361-371. 
41. Zeilinger SM Omann (2007) Trichoderma biocontrol: Signal transduction pathways involved in host sensing and mycoparasitism. Gene Regul Syst Bio 1: 227-234

42. Escoubas P, Sollod B, King GF (2006) Venom landscapes: Mining the complexity of spider venoms via a combined cDNA and mass spectrometric approach. Toxicon 47(6): 650-663.

43. Sollod BL, Wilson D, Zhaxybayeva O, Gogarten JP, Drinkwater R, et al. (2005) Were arachnids the first to use combinatorial peptide libraries? Peptides 26(1): 131-139.

44. Norton RS, Pallaghy PK (1998) The cystine knot structure of ion channel toxins and related polypeptides. Toxicon 36(11): 1573-1583.

45. Adams ME (2004) Agatoxins: Ion channel specific toxins from the American funnel web spider, Agelenopsis aperta. Toxicon 43(5): 509 525.
46. Li D, Xiao Y, Hu W, Xie J, Bosmans F, et al. (2003) Function and solution structure of hainantoxin-I, a novel insect sodium channel inhibitor from the Chinese bird spider Selenocosmia hainana1. FEBS Lett 555(3): 616622.

47. Gordon D, Karbat I, Ilan N, Cohen L, Kahn R, et al. (2007) The differential preference of scorpion $\alpha$-toxins for insect or mammalian sodium channels: Implications for improved insect control. Toxicon 49(4): 452472 .

48. Herzig V, Ikonomopoulou M, Smith JJ, Dziemborowicz S, Gilchrist J, et al. (2016) Molecular basis of the remarkable species selectivity of an insecticidal sodium channel toxin from the African spider Augacephalus ezendami. Scientific Reports 6: 1-11.

For possible submissions Click below: 